\title{
Effect of therapeutic hypothermia on superficial surgical site infection and postoperative pain in urgent abdominal surgery
}

\author{
당 Erol Kılıç, M.D., () Mustafa Uğur, M.D.
}

Department of General Surgery, Mustafa Kemal University Faculty of Medicine, Hatay-Turkey

\begin{abstract}
BACKGROUND: Although therapeutic hypothermia has been shown to be effective on surgical site infection and postoperative pain in patients undergoing elective surgery, its exact effect on emergency laparotomy remains unclear. In this study, we aimed to investigate the effect of therapeutic hypothermia on superficial surgical site infection and postoperative pain in patients undergoing urgent open abdominal surgery.

METHODS: The study included 100 patients who underwent emergency open abdominal surgery from 01/01/2016 to $01 / 01 / 2017$. The patients were randomly divided into two groups: therapeutic hypothermia, group I underwent cold therapy with local sterile frozen ice compress; and control group II, underwent conventional sterile compress. Age, gender, primary pathology diagnosis, size of incision, wound type and size, and duration of surgery were compared between the groups. Visual analog scale scores were determined every 3 hours, and the requirement for analgesics was assessed for each patient within 48 hours postoperatively. Both before and after 5 days of laparotomy, c-reactive protein (CRP), white blood cell count (WBC), albumin, serum total antioxidant status, and total oxidant status levels were measured, and oxidative stress index was calculated for each patient. The rates of superficial surgical site infection were compared between both groups.
\end{abstract}

RESULTS: The two groups were similar in terms of age, gender, primary pathology diagnosis, size of incision, wound type and size, and duration of surgery $(p>0.05)$. Although no significant difference was found between the groups with regards to visual analog scale scores $(p>0.05)$, requirement for analgesics was lower in the group I compared to that in the control group ( $p<0.05)$. No significant difference was found between the groups in terms of preoperative WBC, albumin, CRP, serum total antioxidant status, total oxidant status, and oxidative stress index (OSI) levels $(\mathrm{p}>0.05)$. At postoperative day 5 , serum total antioxidant status level was significantly higher, and OSI level was significantly lower in the group I compared to the respective levels in the control group $(p<0.05)$. Moreover, the superficial surgical site infection rate was significantly lower in the group I $(p<0.05)$.

CONCLUSION: In patients undergoing urgent open abdominal surgery, therapeutic hypothermia led to lower requirement for analgesics and lower superficial surgical site infection rates in the early postoperative period. We consider that therapeutic hypothermia exerts this effect by elevating the serum total antioxidant status level, and decreasing the effects of inflammatory mediators and OSI.

Keywords: Postoperative pain; superficial surgical site infection; therapeutic hypothermia.

\section{INTRODUCTION}

Therapeutic hypothermia (TH) was first described by Hippocrates. It was used for pain relief by ancient Egyptians, Persians, and Romans. TH is still used for pain relief in various injuries, diseases, and invasive approaches. ${ }^{[1-3]}$ Hypothermia exerts its analgesic effect through several mechanisms including sensory nerve inactivation, reduced nerve conduction velocity, activation of inhibitory interneurons (gate mechanism), opposite irritation, endorphin release, and by decreasing the cellular metabolism of enzyme activity. ${ }^{[4]}$ Superficial surgical site infection (SSSI) is a clinical infection that commonly oc-

Cite this article as: Kılıç E, Uğur M. Effect of therapeutic hypothermia on superficial surgical site infection and postoperative pain in urgent abdominal surgery. Ulus Travma Acil Cerrahi Derg 2018;24:417-422.

Address for correspondence: Erol Kılıç, M.D.

Mustafa Kemal Üniversitesi Tıp Fakültesi, Genel Cerrahi Anabilim Dalı, Hatay, Turkey

Tel: +90 326 - 2291000 / 3368 E-mail: ekkilic55@gmail.com

Ulus Travma Acil Cerrahi Derg 2018;24(5):417-422 DOI: 10.5505/tjtes.2018.23345 Submitted: 09.02.2018 Accepted: 31.07.2018 Online: 20.09.2018

Copyright 2018 Turkish Association of Trauma and Emergency Surgery 
curs in the subcutaneous tissue of incision within 30 days after operative procedure. ${ }^{[8]} \mathrm{SSSI}$ is the most common nosocomial infection (30\%) that causes high morbidity and mortality. ${ }^{[9]}$ The SSSI rates have been reported to be $5 \%$ after aseptic procedures and up to $40 \%$ after abdominal procedures that cause contamination, such as colorectal surgery. ${ }^{[10]}$ The effect mechanism of $\mathrm{TH}$ in the activation of the immune system against infection is well known: TH decreases the concentration of proinflammatory cytokines such as TNF- $\alpha$, IL-I $\beta$, IL-6, and IL-2 while increasing the release of anti-inflammatory cytokines such as IL-10. ${ }^{[1-13]}$ Moreover, TH decreases the serum levels of traditional adhesion molecules that have a role in leukocyte transmigration (ICAM-I, E-Selectin, VCAM). ${ }^{[14-16]}$

Literature reviews indicate that the effect of hypothermia on postoperative pain and surgical site infection has been extensively studied. However, to our knowledge, no study investigates the effect of hypothermia in patients undergoing emergency laparotomy who have been shown to have high rates of surgical site infection. Therefore, this study was aimed to investigate the effect of $\mathrm{TH}$ on SSSI and postoperative pain in such patients.

\section{MATERIALS AND METHODS}

The study was designed as a single-center and double-blind study, and it was conducted at Mustafa Kemal University Medical School General Surgery Department following the approval of Mustafa Kemal University Clinical Research Ethics Committee (Approval date, January 17, 2015; No. 4298783/05003). The study was funded by Mustafa Kemal University Scientific Research Projects Directory (Decree No. 13660).

The study included 100 patients who underwent emergency laparotomy with midline incision within a period of I year from $0 \mathrm{I} / 0 \mathrm{I} / 20 \mathrm{I} 6$ to $0 \mathrm{I} / 0 \mathrm{I} / 20 \mathrm{I}$. Patients with a serious medical disease, obesity (BMI >35), malnutrition, cachexia (BMI $<18$ ), immunosuppression, and diabetes mellitus as well as and patients who were receiving corticosteroid treatment and had a history of smoking were excluded from the study.

Preoperative SSSI prophylaxis was performed with intravenous (IV) quinolone (ciprofloxacin, $200 \mathrm{mg}$ IV) $60 \mathrm{~min}$ prior to the anesthetic induction. After the induction, the skin hair was removed using a shaving machine. All the surgical procedures were performed under general anesthesia. Anesthesia was induced with IV propofol $(2 \mathrm{mg} / \mathrm{kg}$ ), remifentanil (I mcg/ $\mathrm{kg})$, and rocuronium $(0.6 \mathrm{mg} / \mathrm{kg})$. Anesthesia was maintained with sevoflurane and $50 \% \mathrm{~N}_{2} \mathrm{O}$ in oxygen. At the end of the surgery, all the patients were administered tramadol $100 \mathrm{mg}$ IV and acetaminophen I $\mathrm{g}$ for postoperative pain relief prior to extubation.

The patients were randomized by computer, and they were divided into two equal groups: (I) the TH group $(n=50)$ un- derwent $\mathrm{TH}$ within the first hour after the surgery, and (II) the control group $(n=50)$ did not undertake $\mathrm{TH}$. The $\mathrm{TH}$ group underwent cold therapy with local sterile frozen ice compress (Alkantis ${ }^{\circledR}$, France), whereas the control group underwent conventional sterile compress. In both groups, wound dressing was changed every 3 hours, and the surgical site was left closed for 48 hours.

Age, gender, primary pathology diagnosis, history of diseases, preoperative antimicrobial treatment, total blood loss, requirement for blood transfusion, size of incision, and wound type and size were recorded for each patient. Visual analog scale (VAS) scores were determined every $3 \mathrm{~h}$, and the requirement for nonsteroidal anti-inflammatory drugs (NSAIDs) and opioid drugs was assessed for each patient within $48 \mathrm{~h}$ postoperatively. Patients with a VAS score of $>4$ were administered $75 \mathrm{mg}$ diclofenac in a single intramuscular (IM) injection. If the VAS score was still >4 after $20 \mathrm{~min}, \mathrm{I} \mathrm{mg/}$ $\mathrm{kg}$ of pethidine hydrochloride $\left(\right.$ Aldolan $^{\circledR}$ ) was infused in $50 \mathrm{cc}$ saline solution for $10 \mathrm{~min}$.

All the patients were planned for emergency laparotomy. Both before and after 5 days of the emergency laparotomy, c-reactive protein (CRP), white blood cell count (WBC), albumin, serum total antioxidant status (TAS), and total oxidant status (TOS) levels were measured, and oxidative stress index (OSI) was calculated for each patient. WBC was measured by a fully automated hematology analyzer (Mindray ${ }^{\circledR}$, UK). Fasting venous blood samples were centrifuged at $1500 \mathrm{~g}$, and serum was separated. Serum TAS and TOS levels were measured using the spectrophotometric method developed by Erel (Rel Assay Diagnostics Kits, Mega TIp ${ }^{\circledR}$, Turkey). ${ }^{[17,18]}$ OSI was calculated based on the following formula: OSI (arbitrary unit) $=\operatorname{TOS}\left(\mu \mathrm{mol} \mathrm{H}_{2} \mathrm{O}_{2} \mathrm{Eq} / \mathrm{L}\right) / \mathrm{TAS}$ ( $\mu \mathrm{mol}$ Trolox Eq/L). Serum albumin levels were spectrophotometrically measured using an auto analyzer (ArchitectR c8000, Clinical Chemistry Analyzer, Abbott, USA), and serum CRP levels were measured using the nephelometric method (Immage Nephelometer ${ }^{\circledR}$, Beckman Coulter Inc., USA).

SSSI was identified based on the Centers for Disease Control and Prevention's National Healthcare Safety Network classification for surgical site infection, and was it followed up for 30 days postoperatively. ${ }^{[19]}$ SSSI was accepted as clinical presentation of rash, edema, local heat elevation, and purulent discharge in the surgical site within this period, and culture analysis and treatment were performed accordingly.

\section{Statistical Analysis}

Data were analyzed using SPSS 23 (IBM SPSS Statistics for Windows, Armonk, NY, USA). Normal distribution was tested using the Shapiro-Wilk Normality Test. Variables with normal distribution were compared using the t-test. Variables with nonnormal distribution were compared using Mann-Whitney $U$ test and Wilcoxon test. Categorical 
variables were analyzed using the chi-square test. Variables with normal distribution were expressed as mean \pm standard deviation, and variables with nonnormal distribution were expressed as median (minimum-maximum). Categorical variables were expressed as frequencies and percentages. A $\mathrm{P}$ value of $<0.05$ was considered significant.

\section{RESULTS}

The two groups were similar in terms of age, gender, primary pathology diagnosis, size of incision, and wound type and size, and duration of surgery $(p>0.05)$ (Table I). In addition, the groups were also similar with regards to wound size $(\mathrm{cm})$, duration of surgery, preoperative TAS, TOS, OSI, albumin, CRP, and WBC levels, total blood loss, and requirement for blood transfusion ( $p>0.05)$ (Table 2).

Preoperative TAS levels were significantly higher in the $\mathrm{TH}$ group compared to those in the control group (1.618 \pm 0.253 vs. I.50I $\pm 0.232 \mathrm{mmol}$ TroloxEq/L) $(p<0.05)$. Postoperative TOS levels were almost similar in both groups $(p>0.05)$. Postoperative OSI levels were significantly lower in the $\mathrm{TH}$ group compared to those in the control group (I $4.4 \pm 2.9$ vs.

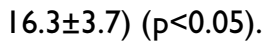

The mean VAS scores measured at 0-24 $\mathrm{h}$ and 24-48 $\mathrm{h}$ postoperatively were the same in both groups (8/6 vs. $8 / 6$, respectively) ( $p>0.05)$. However, mean diclofenac consump- tion at $24-48 \mathrm{~h}$ postoperatively was significantly lower in the $\mathrm{TH}$ group compared to that in the control group $(p<0.05)$. Similarly, mean opioid drug consumption was significantly lower in the TH group both at 0-24 h and 24-48 h postoperatively compared to that in the control group $(p<0.05)$ (Table 2).

SSSI was detected in II (22\%) patients in the $\mathrm{TH}$ group and in 17 (34\%) patients in the control group, and a significant difference was found between the two groups $(p<0.05)$. Moreover, the pathogens isolated from surgical site infections were similar in both groups. The most common pathogen was methicillin-resistant staphylococcus aureus (MRSA), followed by coagulase-negative staphylococci (CoNS), enterococci, and Escherichia coli, respectively (Table 3).

\section{DISCUSSION}

$\mathrm{TH}$ is known to protect tissues against inflammation through its anti-inflammatory effect. Due to this effect, TH is commonly performed in numerous clinical conditions including traumatic brain injury, spinal cord injury, cardiac arrest, and neonatal hypoxic-ischemic encephalopathy. ${ }^{[20,21]}$ Although the exact mechanism of $\mathrm{TH}$ remains unclear, administration of cold compress is known to have an analgesic effect. This effect is considered to arise from several mechanisms including sensory nerve inactivation, reduced nerve conduction velocity, activation of inhibitory interneurons (gate mechanism), and endorphin release. ${ }^{[4,5,22]}$

Table I. Comparison of age, gender, primary pathology diagnosis, and wound type between the two groups

\begin{tabular}{|c|c|c|c|}
\hline & Therapeutic hypothermia $(n=50)$ & Control $(n=50)$ & $\mathbf{p}$ \\
\hline Age & $52.9 \pm 20.5$ & $53.6 \pm 18.2$ & 0.869 \\
\hline \multicolumn{4}{|l|}{ Gender } \\
\hline Female & $20(40)$ & $21(42)$ & 0.839 \\
\hline Male & $30(60)$ & $29(58)$ & \\
\hline \multicolumn{4}{|l|}{ Primary pathology } \\
\hline Gastrointestinal perforation & $17(34)$ & $14(28)$ & \\
\hline Intestinal obstruction & $8(16)$ & II (22) & \\
\hline Acute cholecystitis-cholangitis & $6(12)$ & $6(12)$ & \\
\hline Incarcerated ventral hernia & $5(10)$ & $3(6)$ & \\
\hline Acute appendicitis & $3(6)$ & $4(8)$ & \\
\hline Liver/spleen laceration & $3(6)$ & $3(6)$ & \\
\hline Strangulated inguinal hernia & $3(6)$ & $3(6)$ & \\
\hline Gastrointestinal hemorrhage & $2(4)$ & $3(6)$ & \\
\hline Acute necrotizing pancreatitis & $2(4)$ & $2(4)$ & \\
\hline Mesenteric ischemia & I (2) & I (2) & \\
\hline \multicolumn{4}{|l|}{ Wound type } \\
\hline 2 & $14(28)$ & $13(26)$ & 0.900 \\
\hline 3 & $31(62)$ & $33(66)$ & \\
\hline 4 & $5(10)$ & $4(89)$ & \\
\hline
\end{tabular}


Table 2. Comparison of parameters between the groups

\begin{tabular}{|c|c|c|c|}
\hline & TH $(n=50)$ & Control $(n=50)$ & $\mathbf{p}$ \\
\hline Size of incision* & $19.3 \pm 3.3$ & $19.2 \pm 3.1$ & 0.852 \\
\hline Duration of surgery $(\mathrm{min})^{* *}$ & $132.5(55-185)$ & $135(95-1445)$ & 0.246 \\
\hline Total antioxidant status $\mu \mathrm{mol} \mathrm{H}_{2} \mathrm{O}_{2} \mathrm{Eq} / \mathrm{L}^{* *}$ & $1.413 \pm 0.258$ & $1.389 \pm 0.332$ & 0.617 \\
\hline Total antioxidant status mmol TroloxEq/L (Postop day 5) & $1.618 \pm 0.253$ & $1.50 I \pm 0.232$ & 0.017 \\
\hline Total oxidant status $\mu \mathrm{mol} \mathrm{H}_{2} \mathrm{O}_{2} \mathrm{Eq} / \mathrm{L}^{* *}$ & $25.478(11.15-38.782)$ & $26.632(12.15-38.354)$ & 0.918 \\
\hline Total oxidant status mmol TroloxEq/L (Postop day 5) & $23.094(16.50-39.145)$ & $24.690(12.467-37.478)$ & 0.182 \\
\hline Oxidative stress index (AU) (Postop day 5$)^{*}$ & $14.4 \pm 2.9$ & $16.3 \pm 3.7$ & 0.004 \\
\hline Albumin $\mathrm{g} / \mathrm{dL}^{*}$ & $3.0 \pm 0.4$ & $3.1 \pm 0.6$ & 0.520 \\
\hline Albumin g/dL (Postop day 5$)^{* * *}$ & $2.9(2.1-4.8)$ & $2.9(1.5-4.4)$ & 0.504 \\
\hline C-reactive protein $\mathrm{mg} / \mathrm{L}^{* *}$ & $98(25-199)$ & $80(21-199)$ & 0.094 \\
\hline C-reactive protein mg/L (Postop day 5$)^{* *}$ & $55(9-149)$ & $64.5(22-190)$ & 0.093 \\
\hline White blood cell count $10^{3} / \mu \mathrm{L}^{* *}$ & $13.6(5.5-24.9)$ & I $3.8(5.6-22.6)$ & 0.923 \\
\hline White blood cell count $10^{3} / \mu \mathrm{L}$ (Postop day 5$)^{* *}$ & $6.1(3.6-17.3)$ & $5.6(3.6-17.4)$ & 0.505 \\
\hline Blood loss $(\mathrm{mL})^{* *}$ & $180(100-1500)$ & $190(130-1350)$ & 0.712 \\
\hline Transfusion $(\mathrm{u})^{* *}$ & $4(3-49)$ & $4(3-4)$ & 0.892 \\
\hline Pain score $0-24 \mathrm{~h}^{* *}$ & $8(5-9)$ & $8(5-9)$ & 1.000 \\
\hline Pain score $24-48 \mathrm{~h}^{* *}$ & $6(3-7)$ & $6(3-7)$ & 1.000 \\
\hline Nonsteroidal anti-inflammatory drugs deliver $0-24 \mathrm{~h}^{* *}$ & $4(3-5)$ & $4(3-5)$ & 1.000 \\
\hline Nonsteroidal anti-inflammatory drugs deliver $24-48 \mathrm{~h}^{* *}$ & $2(I-3)$ & $3(1-4)$ & 0.010 \\
\hline Opioid deliver $0-24 \mathrm{~h}^{* *}$ & $2(2-3)$ & $3(3-4)$ & $<0.001$ \\
\hline Opioid deliver $24-48 \mathrm{~h}^{* *}$ & I (0-3) & $2(0-3)$ & 0.002 \\
\hline
\end{tabular}

"Arithmetic mean \pm standard deviation; " Median (minimum-maximum). TH: Therapeutic hypothermia.

Table 3. Comparison of the SSSI pathogens isolated in both groups

\begin{tabular}{lccccccc}
\hline Pathogen & \multicolumn{2}{c}{ TH $(\mathbf{n = 5 0 )}$} & & \multicolumn{2}{c}{ Control $(\mathbf{n = 5 0 )}$} & p \\
\cline { 2 - 3 } & $\mathbf{n}$ & $\%$ & & $\mathbf{n}$ & $\%$ & \\
\hline SSSI & 11 & 22 & & 17 & 34 & $<0.05$ \\
MRSA & 4 & 8 & & 6 & 12 & $<0.05$ \\
CoNS & 3 & 6 & & 5 & 10 & \\
Enterococcus species & 2 & 4 & & 3 & 6 & \\
Escherichia coli & 2 & 4 & & 3 & 6 & \\
\hline
\end{tabular}

SSSI: Superficial surgical site infection; TH: Therapeutic hypothermia. MRSA: Methicillin-resistant staphylococcus aureus; CoNS: Coagulase-negative staphylococci.

$\mathrm{TH}$ is also known to have a major role in the suppression of neuroapoptosis, reduction of the metabolic rate of neurons, and the inhibition of nitric oxide and reactive oxygen species (ROS). ${ }^{[23]}$ Overproduction of ROS during inflammation leads to an imbalance between ROS production and the antioxidants in the body, thereby leading to tissue degeneration and ultimately to oxidative stress. ${ }^{[2]}$ Moreover, if this imbalance is in favor of oxidative stress, lipid peroxidation occurs, thus leading to apoptosis because of an impairment in the cellular
DNA and membrane structure. ${ }^{[25]}$ In the case of antioxidant depletion, however, peroxyl radicals form covalent bonds with each other, thereby causing impairment of membrane functioning and loss of membrane fluidity. In turn, a decrease in membrane potential leads to increased ion permeability, leading to membrane rupture. As a result, the mitochondrial and other organelle contents are released into the cytoplasm, thus causing cell damage/death. ${ }^{[26]}$ Oxidative stress occurs when the tissue damage caused by active oxidants cannot be prevented by the antioxidant mechanism. In addition, oxidative stress triggers protein denaturation, DNA damage, and lipid peroxidation, thus leading to impairment in the metabolic activity. ${ }^{[27,28]}$ TOS and TAS are commonly measured to predict the total oxidant/antioxidant status of the body. ${ }^{[17,18]}$ In particular, TAS is used for estimating the activity of antioxidants in serum. ${ }^{[29]}$ To determine the status of oxidative stress, OSI is calculated based on the TOS and TAS levels. ${ }^{[23,30]}$

In this study, we also calculated OSI to determine the status of inflammatory responses for each patient. Although TH led to no change in the TOS levels, it resulted in a significant increase in the TAS levels and a decrease in the OSI levels. This finding suggests that the ROS in inflammatory tissues 
are eliminated more effectively, implicating that the extent of tissue damage in patients undergoing $\mathrm{TH}$ is relatively lower, and thus, these patients require less analgesics compared to patients not receiving $\mathrm{TH}$.

Risk factors of SSls include presence of a pre-existing infection, inadequate skin preparation, hair removal and antibiotic choice, administration, and duration. ${ }^{[19]}$ Intraoperative risk factors of SSIs include duration of surgery, blood transfusion, maintenance of asepsis, poor-quality surgical hand scrubbing and gloving, hypothermia, and poor glycemic control. ${ }^{[31]}$ SSSI typically occurs within the first 5 days after surgical procedure. Common laboratory parameters for infection include WBC, CRP, and albumin levels. ${ }^{[32]}$ To prevent SSSI, preoperative antibiotic prophylaxis should be performed, and a second dosage should be administered in surgeries lasting more than 2 h. ${ }^{[33]}$ Most common pathogens causing SSSI include MRSA, CoNS, enterococci, and Escherichia coli. ${ }^{[34]} \mathrm{TH}$ decreases the concentration of pro-inflammatory mediators while increasing the release of anti-inflammatory mediators and preventing leukocyte migration. ${ }^{[1-13]}$

In our study, the risk factors for SSSI and the pathogens isolated from surgical site infections were similar to those reported in the literature. To determine the status of inflammatory responses, we measured the TAS, TOS, and OSI levels in addition to the WBC, CRP, and albumin levels. SSSI was less common in the TH group. Moreover, serum WBC and CRP levels were slightly lower in the $\mathrm{TH}$ group compared to those in the control group, although no significant difference was found in the albumin levels between the two groups. We consider that this effect of TH arises from elevated TAS levels because increased antioxidant activity not only prevents excessive leukocyte migration but also eliminates the ROS more effectively, thereby preventing the formation of ischemic and necrotic tissues that establish a favorable local environment for bacterial proliferation.

In conclusion, in patients undergoing emergency open abdominal surgery, $\mathrm{TH}$ led to lower requirement for analgesics and lower SSSI rates in the early postoperative period. We consider that TH exerts this effect by elevating the TAS level, eliminating ROS, and decreasing the effects of inflammatory mediators. Nevertheless, further studies are needed to provide more substantial findings related to the role of $\mathrm{TH}$ in the prevention or reduction of postoperative pain and SSSI.

Conflict of interest: None declared.

\section{REFERENCES}

1. Trescot AM. Cryoanalgesia in interventional pain management. Pain Physician 2003;6:345-60.

2. Saeliw P, Preechawai P, Aui-aree N. Evaluating the effects of ice application on patient comfort before and after botulinum toxin type A injections. J Med Assoc Thai 2010;93:1200-4.
3. Taghizadeh F, Ellison T, Traylor-Knowles M. Evaluation of pain associated with facial injections using CoolSkin in rhytidectomy. J Pain Res 2011;4:309-13. [CrossRef]

4. Algafly AA, George KP. The effect of cryotherapy on nerve conduction velocity, pain threshold and pain tolerance. Br J Sports Med 2007;41:3659. [CrossRef]

5. Herrera E, Sandoval MC, Camargo DM, Salvini TF. Motor and sensory nerve conduction are affected differently by ice pack, ice massage, and cold water immersion. Phys Ther 2010;90:581-91. [CrossRef]

6. McMeeken J, Lewis MM, Cocks S. Effects of cooling with simulated ice on skin temperature and nerve conduction velocity. Aust J Physiother 1984;30:111-4. [CrossRef]

7. Zachariassen KE. Hypothermia and cellular physiology. Arctic Med Res 1991;50 Suppl 6:13-7.

8. Centers for Disease Control and Prevention (CDC). Surgical Site Infection (SSI) Event. Atlanta: CDC; 2013. Available at: http://www.cdc. gov/nhsn/pdfs/pscmanual/9pscssicurrent.pdf. Accessed Sept 13, 2018.

9. Ott E, Saathoff S, Graf K, Schwab F, Chaberny IF. The prevalence of nosocomial and community acquired infections in a university hospital: an observational study. Dtsch Arztebl Int 2013;110:533-40. [CrossRef]

10. Bratzler DW, Dellinger EP, Olsen KM, Perl TM, Auwaerter PG, Bolon MK, American Society of Health-System Pharmacists; Infectious Disease Society of America; Surgical Infection Society; Society for Healthcare Epidemiology of America. Clinical practice guidelines for antimicrobial prophylaxis in surgery. Am J Health Syst Pharm 2013;70:195-283.

11. Lim CM, Kim MS, Ahn JJ, Kim MJ, Kwon Y, Lee I, et al. Hypothermia protects against endotoxin-induced acute lung injury in rats. Intensive Care Med 2003;29:453-9. [CrossRef]

12. Fujimoto K, Fujita M, Tsuruta R, Tanaka R, Shinagawa H, Izumi T, et al. Early induction of moderate hypothermia suppresses systemic inflammatory cytokines and intracellular adhesion molecule- 1 in rats with caerulein-induced pancreatitis and endotoxemia. Pancreas 2008;37:17681. [CrossRef]

13. Lee SL, Battistella FD, Go K. Hypothermia induces T-cell production of immunosuppressive cytokines. J Surg Res 2001;100:150-3. [CrossRef]

14. Meybohm P, Gruenewald M, Zacharowski KD, Albrecht M, Lucius R, Fösel N, et al. Mild hypothermia alone or in combination with anesthetic post-conditioning reduces expression of inflammatory cytokines in the cerebral cortex of pigs after cardiopulmonary resuscitation. Crit Care 2010;14:R21. [CrossRef]

15. Johnson M, Haddix T, Pohlman T, Verrier ED. Hypothermia reversibly inhibits endothelial cell expression of E-selectin and tissue factor. J Card Surg 1995;10:428-35. [CrossRef]

16. Hanusch C, Nowak K, Gill IS, Törlitz P, Rafat N, Mueller AM, et al. Hypothermic preservation of lung allograft inhibits cytokine-induced chemoattractant-1, endothelial leucocyte adhesion molecule, vascular cell adhesion molecule-1 and intracellular adhesion molecule-1 expression. Clin Exp Immunol 2007;149:364-71. [CrossRef]

17. Erel O. A new automated colorimetric method for measuring total oxidant status. Clin Biochem 2005;38:1103-11. [CrossRef]

18. Erel O. A novel automated direct measurement method for total antioxidant capacity using a new generation, more stable ABTS radical cation. Clin Biochem 2004;37:277-85. [CrossRef]

19. National Healthcare Safety Network. Surgical Site Infection (SSI) Event. Atlanta, GA: Centers for Disease Control and Prevention; 2013.

20. Dietrich WD 3rd.Therapeutic hypothermia for spinal cord injury. Crit Care Med 2009;37:S238-42. [CrossRef]

21. Tagin MA, Woolcott CG, Vincer MJ, Whyte RK, Stinson DA. Hypothermia for neonatal hypoxic ischemic encephalopathy: an up- 
dated systematic review and meta-analysis. Arch Pediatr Adolesc Med 2012;166:558-66. [CrossRef]

22. Zencir G, Eser I. Effects of Cold Therapy on Pain and Breathing Exercises Among Median Sternotomy Patients. Pain Manag Nurs 2016;17:40110. [CrossRef]

23. Edwards AD, Yue X, Squier MV, Thoresen M, Cady EB, Penrice J, et al. Specific inhibition of apoptosis after cerebral hypoxia-ischaemia by moderate post-insult hypothermia. Biochem Biophys Res Commun 1995;217:1193-9. [CrossRef]

24. Halliwell B, Aruoma OI. DNA damage by oxygen-derived species. Its mechanism and measurement in mammalian systems. FEBS Lett 1991;281:9-19. [CrossRef]

25. Atlan N, Sepici Dinçel A, Koca C. Diabetes Mellitus and Oxidative Stress. Turk J Biochem 2006;31;51-6.

26. Catalá A. An overview of lipid peroxidation with emphasis in outer segments of photoreceptors and the chemiluminescence assay. Int J Biochem Cell Biol 2006;38:1482-95. [CrossRef]

27. Duracková Z. Some current insights into oxidative stress. Physiol Res 2010;59:459-69.
28. Katsoulis K, Kontakiotis T, Baltopoulos G, Kotsovili A, Legakis IN. Total antioxidant status and severity of community-acquired pneumonia: are they correlated? Respiration 2005;72:381-7. [CrossRef]

29. LeBel CP, Bondy SC. Oxygen radicals: common mediators of neurotoxicity. Neurotoxicol Teratol 1991;13:341-6. [CrossRef]

30. Serafini M, Del Rio D. Understanding the association between dietary antioxidants, redox status and disease: is the Total Antioxidant Capacity the right tool? Redox Rep 2004;9:145-52. [CrossRef]

31. Anderson DJ, Podgorny K, Berríos-Torres SI, Bratzler DW, Dellinger EP, Greene L, et al. Strategies to prevent surgical site infections in acute care hospitals: 2014 update. Infect Control Hosp Epidemiol 2014;35:60527. [CrossRef]

32. Kılıç YA, Abbasoğlu O. Surgical site infections: Introduction and definitions. Hospital Infection Journal 2001;5:63-8.

33. Ban KA, Minei JP, Laronga C, Harbrecht BG, Jensen EH, Fry DE, et al. American College of Surgeons and Surgical Infection Society: Surgical Site Infection Guidelines, 2016 Update. J Am Coll Surg 2017;224:59-74.

34. Owens CD, Stoessel K. Surgical site infections: epidemiology, microbiology and prevention. J Hosp Infect 2008;70 Suppl 2:3-10. [CrossRef]

\section{ORIJIINAL ÇALIŞMA - ÖZET}

\section{Acil abdominal cerrahi geçiren hastalarda yüzeyel cerrahi alan enfeksiyonu ve ameliyat sonrası ağrıya terapötik hipoterminin etkisi}

\section{Dr. Erol Kılıç, Dr. Mustafa Uğur}

Mustafa Kemal Üniversitesi Tıp Fakültesi, Genel Cerrahi Anabilim Dalı, Hatay

AMAÇ: Terapotik hipoterminin, elektif cerrahi uygulanan hastalarda yara yeri enfeksiyonu ve ameliyat sonrası ağrıya etkili olduğu bilinse de, acil laparatomi uygulanan hastalardaki etkisi net bilinmemektedir. Çalışmada hipotezimiz terapotik hipoterminin açık acil abdominal cerrahi uygulanan hastalarda yüzeyel cerrahi alan enfeksiyonu ve ameliyat sonrası ağrıyı azaltacağıdır.

GEREÇ VE YÖNTEM: 2016-2017 tarihleri arasında acil abdominal cerrahi uygulanan hastalar bilgisayar aracılığıla randomize edilerek hastaların yarısına ameliyat sonrası birinci saat içinde steril buz kompres ile lokal soğutma, diğer yarısına klasik steril kompres uygulanarak gruplandırıldı. Grupların yaş, cinsiyet, primer tanı, kesi boyutu, yara tipi, boyutu ve cerrahi süre belirlenerek karşılaştıııldı. Ameliyat sonrası 48 saat boyunca her üç saatte bir vizüel ağrı skorları ile bu dönemlerdeki analjezik gereksinimi belirlenerek gruplar karşılaştırıldı. Tüm hastalardan ameliyat öncesi ve sonrası beşinci günde kan alınarak, C-reaktif protein, beyaz küre, albumin, serum total antioksidan status, total oksidan status seviyeleri ölçüldü, oksidatif stres indeksi hesaplanarak gruplar karşılaştıııldı. Gruplarda gelişen yüzeyel cerrahi alan enfeksiyonu karşılaştırıldı.

BULGULAR: Gruplar arasında yaş, cinsiyet, primer tanı, kesi boyutu, yara tipi, boyutu ve cerrahi süre açısından anlamlı fark yoktu ( $p>0.05)$. Gruplar arasında vizüel ağrı skorları açısından istatiksel açıdan anlamlı fark olmamakla birlikte $(p>0.05)$ steril buz kompres uygulanan grupta analjezik ihtiyacı daha azdı $(p<0.05)$. Ameliyat öncesi lökosit sayısı, albumin, C-reaktif protein, serum total antioksidan status, total oksidan status ve oksidatif stres indeksi açısından fark yoktu ( $>0.05)$. Ameliyat sonrası beşinci günde gruplar arasında serum total antioksidan status düzeyi steril buz kompres uygulanan grupta belirgin olarak artmıştı ve oksidatif stres indeksi belirgin olarak azalmıştı $(p<0.05)$. Yüzeyel cerrahi alan enfeksiyonu steril buz kompres uygulanan grupta belirgin olarak daha azdı $(p<0.05)$.

TARTIŞMA: Terapotik hipotermi/lokal soğutma, acil açık abdominal cerrahi uygulanan hastalarda ameliyat sonrası dönemde analjezik ihtiyacını azaltmaktadır. Ayrıca yüzeyel cerrahi alan enfeksiyonunun gelişmesini önlemektedir. Bu etkileri serum total antioksidan status seviyesini arttırarak oksidatif stres indeksini azaltarak gerçekleştirmektedir.

Anahtar sözcükler: Ameliyat sonrası ağrı; terapotik hipotermi; yara yeri enfeksiyonu.

Ulus Travma Acil Cerrahi Derg 2018;24(5):417-422 doi: 10.5505/tjtes.20।8.23345 